\title{
PERSEKONGKOLAN TENDER DALAM PERSAINGAN USAHA MENURUT UU NO. 5 TAHUN 1999 TENTANG LARANGAN PRAKTIK MONOPOLI DAN PERSAINGAN USAHA TIDAK SEHAT
}

\author{
Dewi Nawang Wulan', Ainul Masruroh ${ }^{2}$, Rusydi $^{3}$ \\ ${ }^{1,2,3}$ Universitas Islam Darul 'Ulum Lamongan \\ 1dewichandrawulan28@gmail.com, ${ }^{2}$ ainul@unisda.ac.id, ${ }^{3}$ rusydi.mh@gmail.com
}

\begin{abstract}
Conspiracy tender an action collusive which can reduce the transparency and honesty among the participants of the tender. While time is the government is already set on Procurement of Goods and / or Services in electronic form of etendering, with the system online are expected to minimize leakage of the tender as well as the level of conspiracy tender there. But in practice leakage tender and conspiracy are still going on between the actors of business, including the Tender Works Revitalization Development Arena Youth / Teens province of West Nusa Tenggara on Year Budget 2011. Setting the tender which already are online should be able to prevent the conspiracy that happen, but in practice conspiracy tender occur with other modes namely with an agreement that is done by the participants of the tender kolusif the form of similarity IP Address, is practices outside the mechanism system of tendering set. Of things that mean conspiracy tender is still going on and still be one of the problems for the world of busines.

Material laws are used as a reference will be analyzed using the technique of analysis of the contents by formulating the analysis of the decision that was decided by the Commission for the Supervision of Competition Usaha (KPPU). Results of the study showed that the system electronics have not fully guarantee the tender free of the conspiracy that carried out by the perpetrators of the business. It is an impact on the budget and the level of competition of business that is healthy, from the system electronics in the form of e-tenderimg the search of a conspiracy can be detected much earlier.
\end{abstract}

Keywords : Conspiracy, Tender, Competition Enterprises

\begin{abstract}
ABSTRAK
Persekongkolan tender merupakan tindakan kolusif yang dapat mengurangi transparansi serta kejujuran diantara peserta tender. Sementara saat ini pemerintah sudah mengatur tentang Pengadaan Barang dan/atau Jasa secara elektronik berupa e-tendering, dengan sistem online tersebut diharapkan dapat meminimalisir kebocoran tender serta tingkat persekongkolan tender yang ada. Namun pada praktiknya kebocoran tender serta persekongkolan masih terjadi diantara pelaku usaha, termasuk dalam Tender Pekerjaan Revitalisasi Pembangunan Gelanggang Pemuda/Remaja Propinsi Nusa Tenggara Barat pada Tahun Anggaran 2011. Pengaturan tender yang sudah secara online mestinya dapat mencegah terjadinya persekongkolan yang terjadi, namun pada praktiknya persekongkolan tender terjadi dengan modus lain yakni dengan perjanjian yang dilakukan oleh peserta tender kolusif tersebut berupa kesamaan IP Address, adanya praktik-praktik diluar mekanisme sistem tender yang ditetapkan. Dari hal tersebut berarti persekongkolan tender masih terjadi serta masih menjadi salah satu permasalahan bagi dunia usaha.
\end{abstract}


Bahan hukum yang dijadikan acuan akan dianalisis menggunakan teknik analisis isi dengan memformulasikan analisis putusan yang diputuskan oleh Komisi Pengawas Persaingan Usaha (KPPU). Hasil penelitian menunjukkan bahwa adanya sistem elektronik belum sepenuhnya menjamin tender bebas dari persekongkolan yang dilakukan oleh para pelaku usaha. Hal ini berdampak pada anggaran serta tingkat persaingan usaha yang sehat, dari adanya sistem elektronik berupa etenderimg tersebut penelusuran tentang persekongkolan dapat dideteksi lebih dini.

\section{Kata Kunci : Persekongkolan, Tender, Persaingan Usaha}

\section{PENDAHULUAN}

UU No. 5 Tahun 1999 tentang Larangan Praktik Monopoli dan Persaingan Usaha Tidak Sehat telah disahkan pada tanggal 5 Maret 1999. Kehadiran undangundang ini diharapkan dapat menciptakan suasana kondusif bagi pelaku usaha sehingga mampu mengantarkan Indonesia dalam kancah globalisasi, karena persaingan adalah suatu elemen yang esensial dalam perekonomian modern sebagai syarat mutlak terselenggaranya ekonomi pasar.

Salah satu substansi yang merupakan bagian kegiatan yang dilarang dalam UU No. 5 Tahun 1999 adalah ketentuan yang mengatur tentang persekongkolan tender. Ketentuan tersebut diatur dalam Pasal 22 UU No. 5 Tahun 1999, dan merupakan ketentuan yang lebih khusus sifatnya dalam rangka menciptakan iklim usaha yang kondusif guna mendukung dan menumbuh kembangkan kegiatan penyediaan barang dan/atau jasa yang berkualitas serta harga yang bersaing di tanah air.

Pengertian tender atau lelang diartikan sebagai serangkaian kegiatan untuk menyediakan kebutuhan barang dan/atau jasa yang seimbang dan memenuhi syarat, berdasarkan peraturan tertentu yang ditetapkan oleh pihak terkait. Oleh karena itu, dalam hal ini dikatakan, bahwa tujuan utama pelaksanaan penawaran tender adalah memberikan kesempatan yang seimbang bagi semua penawar, sehingga menghasilkan harga yang paling murah dengan output yang maksimal. Meskipun secara umum diakui, bahwa harga murah bukanlah semata-mata ukuran untuk menentukan kemenangan dalam pengadaan barang dan/atau jasa, namun melalui pengaturan penawaran tender sedapat mungkin dihindarkan kesempatan untuk melakukan konspirasi di antara para pesaing atau antara penawar dengan panitia penyelenggara lelang. 
Konspirasi atau persekongkolan dalam penawaran umum diartikan sebagai bentuk perjanjian kerjasama di antara para penawar yang seharusnya bersaing, dengan tujuan memenangkan peserta tender tertentu. Perjanjian ini dapat dilakukan oleh satu atau lebih peserta lelang yang setuju untuk tidak mengajukan penawaran, atau oleh para peserta lelang yang menyetujui satu peserta dengan harga yang lebih rendah dan kemudian melakukan penawaran dengan harga di atas harga perusahaan yang direkayasa sebagai pemenang.

Pada hakekatnya persekongkolan atau konspirasi bertentangan dengan rasa keadilan, karena tidak memberikan kesempatan yang sama kepada seluruh penawar untuk mendapatkan objek barang dan/atau jasa yang ditawarkan penyelenggara. keadilan adalah a condition in which the optimum balance is achieved between individual aspiration and collective need (which may be seen as a sum total of the combined individual aspirations of the member of a society). ${ }^{1}$ Akibat adanya persekongkolan tender, penawar yang mempunyai iktikad baik menjadi terhambat untuk masuk pasar, dan akibat lebih jauh adalah terciptanya harga yang tidak kompetitif.

Prosedur pelaksanaan tender untuk proyek pengadaan barang dan/atau jasa oleh pemerintah/BUMN/BUMD yang dianggarkan dalam APBN dan APBD diatur dalam Peraturan Presiden Republik Indonesia Nomor 4 Tahun 2015 tentang Perubahan Keempat atas Peraturan Presiden Nomor 54 Tahun 2010 tentang Pengadaan Barang/Jasa Pemerintah (selanjutnya disebut Perpres No. 4 Tahun 2015), Peraturan Presiden ini menggantikan Keppres No. 80 Tahun 2003 tentang Pengadaan Barang dan Jasa.

\section{METODELOGI}

Penelitian ini mencakup bidang materi ilmu hukum. Penelitian yang dilakukan merupakan penelitian hukum normatif atau penelitian hukum doktrinal, yaitu penelitian hukum yang pengkajiannya didasarkan pada kumpulan bahanbahan yang berasal dari bahan hukum primer maupun bahan hukum sekunder yang terkait dengan objek penelitian. Studi ini berkaitan dengan persekongkolan tender yang pengaturan aturannya didasarkan pada UU No. 5 Tahun 1999 terutama dalam

\footnotetext{
${ }^{1}$ Hilaire McCoubrey dan Nigel D. White, Textbook on Jurisprudence, Blackstone Press Ltd., London, 1996, h. 286. Dikutip dalam Ahmad Munir, "Good Governance on Tax Amnesty" 131, no. Iclgg 2017 (2018): 28-32, https://doi.org/10.2991/iclgg-17.2018.5. h. 219-220.
} 
Pasal 22. Sejauh studi itu erat kaitannya dengan subtansi undang-undang maka tidak ada salahnya kalau studi tersebut dikategorikan sebagai studi hukum.

Dalam penelitian ini peneliti akan menggunakan pendekatan perundangundangan karena yang diteliti adalah aturan hukum yang menjadi fokus penelitian ini. Pendekatan kasus (case approach) dengan melakukan telaah pada kasus yang berkaitan dengan isu hukum yang dihadapi dan telah memperoleh putusan berkekuatan hukum tetap yakni melalui Putusan Perkara Nomor 19/KPPU-L/2014, hal pokok yang dikaji pada setiap putusan tersebut adalah pertimbangan hakim untuk sampai pada suatu putusan.

\section{PEMBAHASAN}

\section{Terminologi Persekongkolan Tender Menurut UU No. 5 Tahun 1999}

Persekongkolan atau konspirasi usaha adalah bentuk kerjasama yang dilakukan oleh pelaku usaha dengan pelaku usaha lain dengan maksud untuk menguasai pasar bersangkutan bagi kepentingan pelaku usaha yang bersekongkol".2 Berdasarkan pengertian tersebut, persekongkolan (conspiracy/konspirasi) dapat melibatkan kerjasama antar dua atau lebih pelaku usaha yang secara bersama-sama melakukan tindakan melawan hukum.

Istilah persekongkolan (conspiracy) sebenarnya berasal dari Antitrust Law di USA yang didapat melalui Yurisprudensi Mahkamah Tertinggi Amerika Serikat, berkaitan dengan ketentuan Pasal 1 The Sherman Act 1890, dimana dalam pasal tersebut menyatakan; “...persekongkolan untuk menghambat perdagangan....(.....conspiracy in restraint of trade...)”. Mahkamah Tertinggi USA menciptakan istilah "concerted action", untuk mendefinisikan istilah persekongkolan dalam hal menghambat perdagangan, serta merumuskan prinsip, bahwa terhadap pelaku usaha harus dibuktikan, bahwa terdapat kegiatan saling menyesuaikan yang berlandasakan pada persekongkolan guna menghambat perdagangan serta pembuktiannya dapat disimpulkan dari kondisi yang ada, berdasarkan pengertian di USA itulah maka persekongkolan adalah kesepakatan dalam bentuk kerjasama yang konsekuensinya adalah perilaku yang saling

${ }^{2}$ Pasal 1 huruf (h) Bab I Ketentuan Umum Undang-Undang Nomor 5 Tahun 1999 tentang Larangan Praktik Monopoli dan Persaingan Usaha Tidak Sehat. 
menyesuaikan (conspiracy is an agreement which has consequence of concerted action). ${ }^{3}$

Konspirasi atau persekongkolan dalam penawaran umum diartikan sebagai bentuk perjanjian kerjasama di antara para penawar yang seharusnya bersaing, dengan tujuan memenangkan peserta tender tertentu. Perjanjian ini dapat dilakukan oleh satu atau lebih peserta lelang yang setuju untuk tidak mengajukan penawaran, atau oleh para peserta lelang yang menyetujui satu peserta dengan harga yang lebih rendah, dan kemudian melakukan penawaran dengan harga di atas harga perusahaan yang direkayasa sebagai pemenang. Kesepakatan semacam ini bertentangan dengan proses pelelangan yang wajar, karena penawaran umum dirancang untuk menciptakan keadilan dan menjamin dihasilkannya harga yang murah dan paling efisien.

\section{Persekongkolan dalam perspektif UU no. 5 tahun 1999}

Jika sejumlah pelaku usaha kebanyakan melaksanakan kegiatan atau memiliki perilaku sejajar berdasarkan keyakinan serta harapan, bahwa semua pelaku usaha akan melakukan kegiatan yang sama, maka secara keseluruhan hal ini akan membawa konsekuensi, bahwa mereka sepakat melakukan kegiatan yang sebetulnya dilarang oleh UU Antimonopoli.

Sehingga dalam hal ini persekongkolan dalam perspektif UU No. 5 Tahun 1999 merupakan suatu larangan dalam kesepakatan, perjanjian, kerjasama maupun segala penyesuaian yang berhubungan dengan tender yang dilaksanakan. Segala bentuk kegiatan penyesuaian menurut UU No. 5 Tahun 1999 merupakan kegiatan persekongkolan yang berhubungan dengan Pasal 22. Oleh karena itu pengaturan larangan persekongkolan tender selain diatur dalam Pasal 22 hal ini juga terdapat keterkaitan dengan Pasal-Pasal lain didalam UU No. 5 Tahun 1999.

\section{Ruang lingkup persekongkolan}

Dalam Pasal 22, 23, dan Pasal 24 UU No. 5 Tahun 1999 mensyaratkan adanya persekongkolan yang dilakukan oleh para pelaku usaha dengan pihak lain (pihak ketiga). Persoalan dapat atau tidak dapat diterapkannya ketentuan pasal tersebut bergantung pada 2 (dua) elemen, yaitu adanya para pihak yang terkait yang

\footnotetext{
${ }^{3}$ Knud Hansen, Law Concerning Prohibition of Monopolistic Practices and Unfair Business Competition, Katalis, Jakarta, 2002, h. 323-324. Dikutip dari L. Budi Kagramanto, Ibid., h. 30.
} 
harus atau mampu menunjukkan ciri-ciri ikut berpartisipasi, serta telah terjadi kesepakatan untuk melakukan kegiatan yang saling menyesuaikan dan bersifat kolusif.

Disamping itu terhadap ketentuan Pasal 22, 23 dan Pasal 24 UU No. 5 Tahun 1999 hanya dapat diterapkan, apabila pihak yang satu merupakan pelaku usaha, sedangkan pihak lainnya adalah pihak ketiga. UU No. 5 Tahun 1999 menegaskan, bahwa pihak lain disini tidak harus merupakan pelaku usaha, atau dapat juga pihak lain disini setidak-tidaknya adalah pesaing pihak pertama atau pelaku usaha.

Sedangkan kegiatan yang saling menyesuaikan dan bersifat kolusif merupakan koordinasi yang dilakukan secara sengaja terhadap perilaku pelaku usaha, yang secara faktual maupun yuridis tidak memiliki kekuatan mengikat yang dengan sengaja mengganti persaingan usaha yang penuh dengan risiko dengan kerjasama praktis, sehingga berakibat terbentuknya kondisi pasar yang tidak sesuai dengan persyaratan persaingan usaha.

Pengaturan Pengadaan Barang dan Jasa Berdasarkan Peraturan Presiden No. 4 Tahun 2015 Tentang Perubahan Keempat Atas Peraturan Presiden No. 54 Tahun 2010 Tentang Pengadaan Barang/Jasa Pemerintah

Perkembangan pengaturan pengadaan barang dan jasa pemerintah sebelumnya diatur dalam Keppres No. 18 Tahun 2000 tentang Pedoman Pelaksanaan Pengadaan Barang/Jasa Instansi Pemerintah yang ditetapkan serta diundangkan di Jakarta pada 21 Februari 2000 dalam Lembaran Negara RI Tahun 2000 No. 15. ${ }^{4}$ Pembentukan Keppres No. 18 Tahun 2000 ini dimaksudkan agar pengadaan barang dan jasa instansi pemerintah dapat dilaksanakan secara efektif dan efisien dengan tetap memperhatikan prinsip-prinsip persaingan usaha yang sehat, transparan serta adil. ${ }^{5}$

\footnotetext{
${ }^{4}$ Keppres 18 Tahun 2000 merupakan tonggak sejarah dalam aturan pengadaan barang/jasa di tanah air. Melalui Keppres inilah kebijakan dan aturan hukum pengadaan barang/jasa mengalami perubahan total pada seluruh aspek. Isu transparansi dan penolakan terhadap perlakuan diskriminatif mempengaruhi pembentukan Keppres ini. Periksa : Y. Sogar Simamora, Prinsip Hukum Kontrak Dalam Pengadaan Barang dan Jasa Oleh Pemerintah, Disertasi Program Studi Doktor Ilmu Hukum, Program Pascasarjana Unair, Surabaya, 2005, h. 52., L. Budi Kagramanto, Ibid, h. 54

${ }^{5}$ Keppres No.18 Tahun 2000 ini merupakan hasil penyempurnaan ketentuan pengadaan barang/jasa oleh pemerintah sejak Keppres No. 11 Tahun 1971 tentang Pedoman Pelaksanaan APBN TA 1973/1974 dan sistematika Keppres No. 18 Tahun 2000 terdiri dari 7 (tujuh) bab meliputi: BAB 1 Ketentuan Umum, BAB II Ketentuan Pengadaan Barang dan/atau Jasa, BAB III
} 
Dalam perkembangan selanjutnya ternyata Keppres No. 18 Tahun 2000 diganti oleh Keppres No. 80 Tahun 2003 yang ditetapkan serta diundangkan di Jakarta pada 3 Nopember 2003 dalam Lembaran Negara RI Tahun 2003 No. 120. Didalam Keppres No. 80 Tahun 2003 ini sudah diatur mengenai pemisahan pengadaan yang dilakukan oleh penyedia barang/jasa dengan pengadaan yang dilakukan sendiri secara swakelola. Pelaksanaan pengadaan barang/jasa secara swakelola ini merupakan pelaksanaan pekerjaan yang direncanakan, dikerjakan serta diawasi sendiri, dan kriteria pekerjaan apa saja yang dapat dilaksanakan secara swakelola ini terdapat dalam Lampiran I Keppres No. 80 Tahun 2003 yang memberikan Pedoman jenis dan terinci bagi pengguna barang/jasa dalam melakukan pengadaan secara swakelola.

Bahwa Perpres No. 54 Tahun 2010 yang diperbarui dengan Perpres No. 4 Tahun 2015 merupakan aturan yang menggantikan Keppres No. 80 Tahun 2003. Dalam Pasal 135 Perpres No. 54 Tahun 2010 dinyatakan bahwa Keppres No. 80 Tahun 2003 sebagaimana telah beberapa kali diubah terakhir dengan Perpres No. 95 Tahun 2007, dicabut dan dinyatakan tidak berlaku sejak tanggal 1 Januari 2011.

Berdasarkan Undang-Undang No. 10 Tahun 2004 tentang Pembentukan Peraturan Perundang-undangan, peraturan perundang-undangan yang dikeluarkan oleh Presiden adalah berupa Peraturan Presiden. ${ }^{6}$ Peraturan Perudang-undangan adalah peraturan tertulis yang dibentuk oleh lembaga negara atau pejabat yang berwenang dan mengikat secara umum. Karena sifatnya yang mengikat secara umum, maka bentuk yang dipakai adalah Peraturan Presiden bukan Keputusan Presiden.

\section{Etika pengadaan barang dan jasa}

Selain menerapkan prinsip dasar serta kebijakan umum pemerintah yang berkaitan dengan pengadaan barang/jasa, maka dalam Pasal 6 Perpres No. 4 Tahun 2015 juga diatur mengenai etika pengadaan yang harus ditaati, baik oleh pengguna, penyedia barang/jasa serta pihak yang terkait dalam pelaksanaan pengadaan barang/jasa, yakni antara lain :

Pendayagunaan Produksi Dalam Negeri, peran serta usaha kecil/koperasi setempat, BAB IV tentang Protes/Sanggahan dan Pelelangan Gagal/Ulang, BAB V Perjanjian/Kontrak Pengadaan Barang dan/atau Jasa, BAB VI Pembinaan dan Pengawasan, BAB VII Peraturan Peralihan dan BAB VIII Ketentuan Penutup., L. Budi Kagramanto, Ibid. h. 56

${ }^{6}$ Lihat Pasal 1 angka 6 UU No. 10 Tahun 2004 
a. Melaksanakan tugas secara tertib, disertai rasa tanggung jawab untuk mencapai sasaran, kelancaran dan ketepatan tercapainya tujuan Pengadaan Barang/Jasa;

b. Bekerja secara profesional dan mandiri, serta menjaga kerahasiaan Dokumen Pengadaan Barang/Jasa yang menurut sifatnya harus dirahasiakan untuk mencagah terjadinya penyimpangan dalam Pengadaan Barang/Jasa;

c. Tidak saling mempengaruhi baik langsung maupun tidak langsung yang berakibat terjadinya persaingan tidak sehat;

d. Menerima dan bertanggung jawab atas segala keputusan yang ditetapkan sesuai dengan kesepakatan tertulis para pihak;

e. Menghindari dan mencegah terjadinya pertentangan kepentingan para pihak yang terkait, baik secara langsung maupun tidak langsung dalam proses Pengadaan Barang/Jasa;

f. Menghindari dan mencegah terjadinya pemborosan dan kebocoran keuangan negara dalam Pengadaan Barang/Jasa;

g. Menghindari dan mencegah penyalahgunaan wewenang dan/atau kolusi dengan tujuan untuk keuntungan pribadi, golongan atau pihak lain yang secara langsung atau tidak langsung merugikan negara; dan

h. Tidak menerima, tidak menawarkan atau tidak menjanjikan untuk memberi atau menerima hadiah, imbalan, komisi, rabat, dan berupa apa saja dari atau kepada siapapun yang diketahui atau patut diduga berkaitan dengan Pengadaan Barang/Jasa.

\section{Pengaturan E-Tendering}

E-Tendering adalah tata cara pemilihan Penyedia Barang/Jasa yang dilakukan secara terbuka dan dapat diikuti oleh semua Penyedia Barang/Jasa yang terdaftar pada sistem pengadaan secara elektronik dengan cara menyampaikan 1 (satu) kali penawaran dalam waktu yang telah ditentukan. ${ }^{7}$

E-Tendering dilaksanakan dengan menggunakan sistem pengadaan secara elektronik yang diselenggarakan oleh LPSE. ${ }^{8}$ Pelaksanaan pengadaan barang/jasa secara elektronik (E-Procurement) khususnya dengan E-Tendering dapat menyempurnakan sistem pemilihan penyedia barang/jasa pemerintah yang dilakukan selama ini, sehingga lebih meningkatkan transparansi, akuntabilitas, efektivitas dan efisiensi. Selain itu, pengadaan barang/jasa secara elektronik juga dapat mewujudkan satu pasar pengadaan nasional, sehingga meningkatkan akses pasar dan persaingan usaha yang sehat, memudahkan proses monitoring dan audit, serta mampu memberikan akses informasi yang real time. Dengan demikian, inisiatif untuk segera memulai maupun meningkatkan implementasi E-Procurement

\footnotetext{
${ }^{7}$ Pasal 1 angka 39 Perpres No. 4 Tahun 2015 tentang Perubahan Keempat Atas Peraturan Presiden Nomor 54 Tahun 2010 Tentang Pengadaan Barang/Jasa Pemerintah

${ }^{8}$ Pasal 109 ayat (3) Perpres No. 4 Tahun 2015 tentang Perubahan Keempat Atas Peraturan Presiden Nomor 54 Tahun 2010 Tentang Pengadaan Barang/Jasa Pemerintah
} 
sudah menjadi kebutuhan bagi Kementerian/Lembaga/Satuan Kerja Perangkat Daerah/Institusi Lainnya (K/L/D/I). ${ }^{9}$

Menurut Pasal 109 ayat (1) Perpres No. 4 Tahun 2015, ruang lingkup ETendering meliputi proses pengumuman Pengadaan Barang/Jasa sampai dengan pengumuman pemenang.

\section{Pengaturan Larangan Persekongkolan Tender Dalam UU No. 5 Tahun 1999}

Tender dalam pengertian hukum persaingan usaha diartikan sebagai penawaran pengajuan harga untuk memborong suatu pekerjaan dan/atau untuk pengadaan barang atau penyedia jasa. ${ }^{10}$ Tender ditawarkan oleh pengguna barang dan jasa kepada pelaku usaha yang mempunyai kredibilitas dan kapabilitas berdasarkan alasan efektifitas dan efisiensi. Adapun alasan-alasan lain tender pengadaan barang dan jasa adalah $:^{11}$

1. Memperoleh penawaran terbaik untuk harga dan kualitas;

2. Memberi kesempatan yang sama bagi semua pelaku usaha yang memenuhi persyaratan untuk menawarkan barang dan jasanya, serta

3. Menjamin transparansi dan akuntabilitas pengguna barang dan jasa kepada publik, khususnya pengadaan barang dan jasa di lembaga atau instansi pemerintah.

Dengan demikian ruang lingkup tender meliputi :

1. Tawaran untuk mengajukan harga terendah untuk memborong suatu pekerjaan, seperti membangun atau merenovasi gedung pemerintah.

2. Tawaran untuk mengajukan harga terendah untuk pengadaan barang, seperti memasok kebutuhan, alat-alat tulis dan perlengkapan kantor di instansi pemerintah.

3. Tawaran untuk mengajukan harga terendah untuk menyediakan jasa seperti: jasa cleaning service atau jasa konsultan keuangan di lembaga pemerintah. ${ }^{12}$

4. Tawaran untuk mengajukan harga tertinggi seperti penawaran atau penjualan lelang barang-barang inventaris atau barang sitaan pemerintah yang perolehannya melanggar hukum. ${ }^{13}$

\section{Persekongkolan tender berdasarkan pasal 22 UU no. 5 tahun 1999}

Dalam Pasal 22 UU No. 5 Tahun 1999 mensyaratkan adanya persekongkolan yang dilakukan oleh para pelaku usaha dengan pihak lain (pihak

\footnotetext{
${ }^{9}$ Latar Belakang, Lampiran Peraturan Kepala LKPP, Nomor 1 Tahun 2011 tentang Tata Cara E-Tendering, h. 3

${ }^{10}$ Indonesia, Undang-Undang Tentang Larangan Praktik Monopoli dan Persaingan Usaha Tidak Sehat, Op.Cit., Penjelasan Pasal 22., dikutip dari L. Budi Kagramanto, Ibid.

${ }^{11}$ Ibid.

${ }^{12}$ Yakub Adi Krisanto, Analisis Pasal 22 UU No. 5 Tahun 1999 dan Karakteristik Putusan KPPU tentang Persekongkolan Tender, Jurnal Hukum Bisnis 24, No. 2 Jakarta, 2005

${ }^{13}$ KPPU, Pedoman Pasal 22, Op.Cit, h. 7. Dikutip oleh L. Budi Kagramanto, Ibid.
} 
ketiga). Persoalan dapat atau tidak dapat diterapkannya ketentuan pasal tersebut bergantung pada 2 (dua) elemen, yaitu adanya para pihak terkait yang harus atau mampu menunjukkan ciri-ciri ikut berpartisipasi, serta telah terjadi kesepakatan untuk melakukan kegiatan yang saling menyesuaikan dan bersifat kolusif. ${ }^{14}$

Terhadap Pasal 22 UU No. 5 Tahun 1999 hanya dapat diterapkan, apabila pihak yang satu merupakan pelaku usaha, sedangkan pihak lainnya adalah pihak ketiga. UU No. 5 Tahun 1999 menegaskan, bahwa pihak lain disini tidak harus merupakan pesaing pihak pertama, dan juga tidak harus berupa pesaing usaha, atau dapat juga pihak lain disini setidak-tidaknya adalah pesaing pihak pertama atau pelaku usaha. ${ }^{15}$

Kegiatan persekongkolan tender seperti yang diatur dalam Pasal 22 UU No. 5 Tahun 1999 ini mengacu pada tender yang bersifat kolusif. Persekongkolan tender merupakan kegiatan yang saling menyesuaikan dan bersifat kolusif serta ada suatu koordinasi yang dilakukan secara sengaja terhadap perilaku pelaku usaha, yang secara faktual maupun yuridis tidak memiliki kekuatan mengikat, yang dengan sengaja mengganti persaingan usaha yang penuh dengan risiko dengan kerjasama praktis, sehingga berakibat terbentuknya kondisi pasar yang tidak sesuai dengan persyaratan persaingan usaha.

Sifat kolusif yang ada pada kegiatan persekongkolan tender tersebut terjadi apabila para pesaing sepakat untuk mempengaruhi hasil tender demi kepentingan salah satu pihak dengan tidak mengajukan penawaran atau kalaupun mengajukan penawaran akan dilakukan secara berpura-pura (semu). Harapan dari perilaku pelaku usaha yang demikian ini agar pihak yang tidak mengikuti tender tersebut akan mendapatkan giliran pada tender berikutnya yang didasarkan pada kesepakatan yang sudah diatur sedemikian rupa dengan para anggota lainnya yang bergabung dalam kartel (asosiasi usaha tertentu). ${ }^{16}$

Persekongkolan dengan tender kolusif ini juga bermaksud (mempunyai motif) untuk meniadakan persaingan harga serta berusaha untuk menaikkan harga.

\footnotetext{
${ }^{14}$ Ibid.

${ }^{15}$ Ibid. h. 95

${ }^{16}$ Tujuan kartel adalah, bahwa kontrak didapatkan oleh anggota kartel sesuai persetujuan kartel dan hanya dapat dicapai jika para anggota lain tidak mengajukan penawaran atau hanya mengajukan penawaran tender dengan harga yang terlalu mahal (tinggi), sehingga tidak kompetitif. Dikutip dari L. Budi Kagramanto, Ibid.
} 
Disamping itu persekongkolan tender yang bersifat kolusif ini bertujuan, jika posisi yang mengumumkan adanya tender (diumumkan oleh penyelenggara atau panitia tender) ini dapat mengumumkan berbagai persyaratan yang diminta sesuai kualifikasi yang dimiliki oleh pelaku usaha seperti tender, serta berdasarkan itu pula dapat memahami keinginan para penawar yang sekiranya berpotensi untuk mempengaruhi hasil pengumuman yang menguntungkan pihak penawar.

Biasanya pihak penawar yang mempunyai kemampuan dan berpotensi dalam memenangkan penawaran tender ini tidak memperhatikan lagi bagaimana posisi ataupun kepentingan penawar lainnya dalam tender tersebut. Yang penting bagi si pelaku usaha yang mempunyai kemampuan, berpotensi dan tidak lagi memperhatikan kepentingan serta hak yang dimiliki oleh pelaku usaha lain dalam penawaran tender tersebut, akan berusaha untuk menyuap/menyogok atau aksi nepotisme (yang selama ini dikenal dan tetap dipelihara) kepada penyelenggara atau panitia tender. Berkaitan dengan ini UNCTAD menyatakan, bahwa partisipasi aktif oleh para pelaku usaha dalam kegiatan persekongkolan tender dapat dilakukan dalam beberapa bentuk. Misalnya dalam bentuk ${ }^{17}$ :

a. Kesepakatan untuk mengajukan penawaran harga atas barang dan/atau jasa yang sama;

b. Kesepakatan yang berisi ketentuan, siapa yang mengajukan penawaran yang paling baik (termurah) yang nantinya akan menjadi pemenang tender;

c. Kesepakatan yang berisi ketentuan, siapa yang akan melakukan penawaran yang paling mahal yang secara suka rela berkorban untuk tidak menjadi pemenang tender (sehingga peserta tender tersebut harus rela menerima kekalahan, sedangkan dia juga merelakan pelaku usaha lainnya menjadi pemenang tender);

d. Bentuk perjanjian tidak akan melakukan persaingan satu sama lainnya dalam mengajukan penawaran tender;

e. Kesepakatan yang dibuat berdasarkan standar umum untuk menentukan harga atau persyaratan tender;

f. Kesepakatan yang dilakukan oleh para peserta tender untuk memeras peserta tender dari luar yang ingin mengikuti penawaran tender, dimana peserta tender dari luar tersebut tidak dikehendaki kehadirannya oleh para peserta tender yang berencana melakukan persekongkolan tender;

g. Kesepakatan yang sebelumnya mengatur pemenang tender berdasarkan pada rotasi atau perputaran (arisan tender) ataupun berdasarkan pada alokasi geografis maupun alokasi pelanggan;

17 United Nations Conferences on Trade And Development (UNCTAD), Draft Commentaries, 20 Februari 1998, h. 23., dikutip dari L. Budi Kagramanto, Ibid. h. 96 
h. Disamping itu juga disepakati tentang sistem penyediaan ganti rugi (kompensasi) bagi peserta tender yang kalah maupun yang secara suka rela harus mengalah berdasarkan presentase tertentu dari keuntungan yang diperoleh peserta tender yang dimenangkan, yang akan dibagikan pada akhir jangka waktu tertentu.

Sehingga ruang lingkup persekongkolan dalam tender ini terdiri dari beberapa macam metode atau cara yang dilakukan oleh pelaku usaha dengan menciptakan persaingan semu dan kegiatan kolusif. Persaingan semu yang dilakukan dengan kesepakatan yang mengingkari kaidah persaingan yang sehat dilakukan agar dapat menguasai pasar dengan cara yang negatif, hal ini berimbas pada pelaku usaha lain yang ingin berkompetisi secara sehat maupun berimbas pada kebocoran anggaran.

\section{Pedoman pasal 22 UU no. 5 tahun 1999 tentang larangan persekongkolan tender}

Sesuai dengan ketentuan Pasal 35 Huruf (f) bahwa KPPU bertugas untuk menyusun pedoman dan/atau publikasi terkait dengan pengawasan serta pelaksanaan UU No. 5 Tahun 1999. Melalui pedoman tersebut tujuan yang diharapkan adalah dapat memberikan penjelasan secara lengkap dan dapat dimengerti pihak pihak yang terkait terutama pemerintah, pelaku usaha serta aparat penegak hukum maupun masyarakat luas yang secara tidak langsung ikut berperan dalam mewujudkan kondisi persaingan usaha yang sehat terutama dalam tender.

Ada beberapa hal yang melatarbelakangi pembuatan pedoman tersebut, antara lain, yakni: Adanya ketidak jelasan pemahaman dalam pelaksanaan tender yang disesuaikan dengan sistem persaingan usaha yang sebagaimana ditetapkan UU No. 5 Tahun 1999; Pelaksanaan tender yang terdapat dalam Ketentuan Pasal 22 UU No. 5 Tahun 1999 bersifat umum dan kurang memberi penjelasan secara terperinci. Larangan persekongkolan tender dalam Pasal tersebut hanya sebatas pada penentuan dan/atau pengaturan tentang pemenang tender tanpa diberikan penjelasan secara terperinci mengenai cara dan indikator dalam penentuan serta aturan pemenang tender.

Dengan dasar latarbelakang tersebut, KPPU kemudian mencoba menganalisis dan menguaraikan pengertian dan ruang lingkup tender, unsur-unsur, 
bentuk-bentuk maupun indikasi persekongkolan dalam tender yang terdapat dalam ketentuan Pasal 22 UU No. 5 Tahun 1999 dengan penjelasannya sebagai berikut: ${ }^{18}$

Larangan persekongkolan bagi pelaku usaha dengan pelaku usaha lain terdapat dalam Ketentuan Pasal 22 UU No. 5 Tahun 1999 dengan tujuan untuk mengatur dan/atau menentukan pemenang tender yang dapat mengakibatkan persaingan usaha tidak sehat. Beberapa unsur yang terdapat dalam pasal 22 UU No. 5 Tahun 1999 tersebut adalah :

\section{1) Unsur pelaku usaha (Pasal 1 angka (5) UU No. 5 Tahun 1999)}

Pelaku usaha adalah setiap orang perorangan atau badan usaha baik yang berbentuk badan hukum atau bukan badan hukum yang didirikan dan berkedudukan atau melakukan kegiatan dalam wilayah hukum negara Republik Indonesia, baik sendiri maupun bersama-sama melalui perjanjian, menyelenggarakan berbagai kegiatan usaha dalam bidang ekonomi;

\section{2) Unsur bersekongkol}

Pengertian bersekongkol disini adalah kerjasama yang dilakukan oleh pelaku usaha dengan pihak lain atas dasar inisiatif dari siapapun, dengan cara apapun untuk menentukan pemenang tender. Oleh sebab itu unsur persekongkolan dapat dibedakan berdasarkan perilaku, antara lain: ${ }^{19}$

a) Melakukan pendekatan serta mengadakan kesepakatan dengan instansi terkait penyelenggara/panitia tender sebelum pelaksanaan tender yang berkaitan dengan berbagai hal yang dapat mengarah untuk memenangkan pelaku usaha tertentu.

b) Melakukan pendekatan serta mengadakan kesepakatan yang melanggar larangan persekongkolan tender sehubungan dengan spesifikasi, merek, jumlah, tempat serta waktu penyerahan barang dan jasa yang akan ditenderkan.

c) Melakukan pendekatan dan membuat kesepakatan mengenai cara, tempat, waktu serta batasan pengumuman tender.

d) Melakukan komunikasi atau berbagai informasi yang terkait dengan harga yang akan diajukan dalam tender.

e) Pemberian kesempatan secara eksklusif oleh penyelenggara tender atau pihak terkait secara langsung maupun tidak langsung kepada pelaku usaha yang mengikuti tender, dengan cara melawan hukum.

f) Menciptakan persaingan semu antara peserta tender.

${ }^{18}$ KPPU, Pedoman Pasal 22, Op.Cit, h. 7-16.

19 Pedoman Larangan Persekongkolan Tender berdasarkan UU No. 5 Tahun 1999, Tim Penyusun Guideline Tender KPPU, Jakarta 23 Nopember 2004, h. 14-16., dikutip dari L. Budi Kagramanto, Op.Cit, h. 100 
g) Melakukan penyesuaian penawaran antar pelaku usaha dengan pelaku usaha/peserta tender lainnya.

h) Melakukan pembagian kesempatan untuk memenangkan tender secara bergiliran diantara pelaku usaha/peserta tender.

i) Melakukan penyesuaian, termasuk manipulasi persyaratan tender dan penawaran yang diterima untuk melakukan tender.

\section{3) Unsur "pihak lain"}

Dalam persekongkolan, unsur pihak lain menunjukkan bahwa selalu melibatkan lebih dari satu pelaku usaha. Pihak lain disini baik secara horisontal maupun vertikal yang melakukan persekongkolan tender maupun proses penawaran tender tidak terkecuali pelaku usaha sebagai peserta tender maupun subjek hukum lainnya. Ada 3 bentuk dalam persekongkolan tender, yaitu :

Bentuk pertama (I), persekongkolan horizontal,

Adalah kerjasama antar para penawar tender dengan tujuan untuk mengupayakan salah satu pihak yang dirancang untuk dijadikan pemenang dengan cara bertukar informasi mengenai harga serta untuk menaikkan atau menurunkan harga penawaran. Hal ini dilakukan oleh pelaku usaha/peserta tender dengan menciptakan persaingan semu, dalam praktik tersebut bisa dikategorikan dengan tender arisan.

Bentuk kedua (II), persekongkolan vertikal.

Persekongkolan tender secara vertikal terjadi karena adanya kerjasama yang dilakukan oleh peserta tender/penawar dengan panitia pelaksana tender. Persekongkolan ini terjadi dengan pengaturan panitia memberikan kemudahan persyaratan bagi penawar/peserta tender sehingga akhirnya memenangkan tender/penawaran tersebut.

(3) Bentuk ketiga (III), persekongkolan gabungan horizontal dan vertikal.

Gabungan persekongkolan horizontal dan vertikal ini terjadi antara panitia tender atau panitia lelang dengan pelaku usaha, hal ini dapat melibatkan dua atau lebih pihak yang terkait dengan proses tender yang besar kemungkinan terjadi tender fiktif.

\section{4) Unsur mengatur dan/atau menentukan pemenang tender}

Unsur mengatur dan/atau menentukan pemenang tender diartikan sebagai perbuatan para pihak yang terlibat dalam proses tender secara bersekongkol dengan tujuan untuk menyingkirkan pelaku usaha lain sebagai pesaingnya dan/atau untuk 
menentukan pemenang peserta tender tertentu dengan berbagai cara. Pengaturan penentuan pemenang tender tersebut antara lain menerapkan kriteria pemenang, persyaratan teknik, keuangan, spesifikasi, proses tender, dan sebagainya. Hal ini dapat dilakukan secara vertikal maupun horizontal, berarti bahwa dapat dilakukan oleh pelaku usaha maupun panitia pelaksana.

\section{5) Unsur persaingan usaha tidak sehat}

Unsur ini menunjukkan, bahwa persekongkolan menggunakan pendekatan rule of reason, karena dapat dilihat dari kalimat “....sehingga dapat mengakibatkan terjadinya persaingan usaha tidak sehat". ${ }^{20}$ Pendekatan hukum ini dilakukan oleh lembaga pengawas persaingan sebagai pertimbangan atas faktor-faktor kompetitif dan menetapkan kelayakan hambatan perdagangan.

\section{Penerapan pendekatan Rule of Reason dan Per se Illegal dalam hukum persaingan usaha}

Baik pendekatan per se illegal maupun rule of reason telah lama diterapkan untuk menilai apakah suatu tindakan tertentu dari pelaku bisnis melanggar UndangUndang Antimonopoli. Pendekatan Rule of reason adalah suatu pendekatan untuk mengevaluasi akibat perjanjian atau kegiatan usaha tertentu, guna menentukan apakah suatu perjanjian atau kegiatan tersebut bersifat menghambat atau mendukung persaingan. Sedangkan per se illegal adalah suatu pendekatan yang menyatakan setiap perjanjian usaha atau kegiatan usaha tertentu sebagai ilegal tanpa perlu pembuktian lebih lanjut atas dampak yang ditimbulkan dari perjanjian atau kegiatan usaha tersebut. Kegiatan yang dianggap sebagai per se illegal biasanya meliputi penetapan harga secara kolusif atas produk tertentu, serta pengaturan harga penjualan kembali.

Kedua metode pendekatan yang memiliki perbedaan ekstrim tersebut juga digunakan dalam UU No. 5 Tahun 1999 tentang Larangan Praktik Monopoli dan Persaingan Usaha Tidak Sehat. Hal ini dapat dilihat dari ketentuan pasal-pasalnya, yakni pencantuman kata-kata "yang dapat mengakibatkan" dan/atau "patut diduga". Kata-kata tersebut menyiratkan perlunya penelitian secara lebih mendalam, apakah suatu tindakan dapat menimbulkan praktik monopoli yang bersifat menghambat persaingan. Sementara itu, penerapan pendekatan per se illegal biasanya digunakan

\footnotetext{
${ }^{20}$ L. Budi Kagramanto, Ibid. h. 110
} 
dalam pasal-pasal yang menyatakan istilah "dilarang", tanpa anak kalimat “.....yang dapat mengakibatkan....." oleh karena itu, penyelidikan terhadap beberapa perjanjian atau kegiatan usaha, misalnya kartel (Pasal 11) dan praktik monopoli (Pasal 17) dianggap menggunakan pendekatan rule of reason; sedangkan pemeriksaan terhadap perjanjian penetapan harga (Pasal 5) dan persekongkolan pemenang tender (Pasal 22), persekongkolan informasi kegiatan usaha (Pasal 23) serta persekongkolan untuk menghambat produksi dan/atau pemasaran barang dan/atau jasa (Pasal 24) dianggap menggunakan pendekatan per se illegal.

Penggunaan kedua pendekatan secara alternatif memiliki tujuan yang sama, yakni bagaimana tindakan pelaku usaha tidak menghambat persaingan sehingga mengakibatkan hilangnya efisiensi, yang pada akhirnya menimbulkan kerugian terhadap konsumen. Sementara itu, tujuan pembentukan UU No. 5 Tahun 1999, antara lain adalah menciptakan efisiensi dalam kegiatan usaha serta meningkatkan kesejahteraan rakyat (Pasal 3).

\section{a. Pendekatan per se illegal dan penerapannya}

Pendekatan per se illegal memiliki kekuatan mengikat yang lebih luas daripada larangan-larangan yang tergantung pada evaluasi mengenai pengaruh kondisi pasar yang kompleks. Oleh karena itu, penggunaan pendekatan ini dapat memperpendek proses pada tingkatan tertentu dalam pelaksanaan sebuah undangundang. Suatu proses dianggap relatif mudah dan sederhana. Karena hanya meliputi identifikasi perilaku yang tidak sah dan pembuktian atas perbuatan illegal tersebut. Dalam hal ini tidak deiperlukan lagi penyelidikan terhadap situasi serta karakteristik pasar.

Suatu perilaku yang ditetapkan oleh pengadilan sebagai per se illegal akan dihukum tanpa proses penyelidikan yang rumit. Jenis perilaku yang ditetapkan secara per se illegal hanya akan dilaksanakan, setelah pengadilan memiliki pengalaman yang memadai terhadap perilaku tersebut, yakni bahwa perilaku tersebut hampir selalu bersifat anti persaingan dan hampir selalu tidak pernah membawa manfaat sosial. Pendekatan per se illegal ditinjau dari sudut proses administratif adalah mudah. Hal ini terjadi karena metode ini membolehkan pengadilan untuk menolak melakukan penyelidikan secara rinci, yang biasanya 
memerlukan waktu lama dan biaya yang mahal guna mencari fakta di pasar yang bersangkutan.

Oleh karena itu, pada prinsipnya terdapat dua syarat dalam melakukan pendekatan per se illegal, yakni pertama harus ditujukan lebih kepada "perilaku bisnis" daripada situasi pasar, karena keputusan melawan hukum dijatuhkan tanpa disertai pemeriksaan lebih lanjut, misalnya mengenai akibat dan hal-hal yang melingkupinya. Metode pendekatan seperti ini dianggap fair, jika perbuatan ilegal tersebut merupakan "tindakan sengaja" oleh perusahaan, yang seharusnya dapat dihindari. Kedua, adanya identifikasi secara cepat atau mudah mengenai jenis praktik atau batasan perilaku yang terlarang. Dengan perkataan lain, penilaian atas tindakan dari pelaku usaha, baik di pasar maupun dalam proses pengadilan harus dapat ditentukan dengan mudah. Meskipun demikian, diakui bahwa terdapat perilaku yang terletak dalam batas-batas yang tidak jelas antara perilaku terlarang dan perilaku yang sah.

Tindakan terlarang yang biasanya terjadi dalam bisnis adalah persekongkolan dalam penawaran tender. Apabila melihat bunyi kata-kata dalam Pasal 22 UU No. 5 Tahun 1999, maka ketentuan ini menggunakan pendekatan per se illegal karena terdapat kata "dilarang" juga disertai anak kalimat bersayap "yang dapat mengakibatkan". Bila dikaji lebih jauh, tindakan ini lebih cenderung sebagai "pelaku bisnis" semata dari pada "situasi pasar", sehingga ketentuan tersebut lebih tepat menggunakan pendekatan per se illegal.

\section{b. Pendekatan rule of reason dan penerapannya}

Berbeda halnya dengan per se illegal, penggunaan pendekatan rule of reason memungkinkan pengadilan untuk melakukan interpretasi terhadap undangundang. Masing-masing pendekatan tersebut mengandung keunggulan dan kelemahan yang mungkin dapat menjadi bahan pemikiran untuk menerapkan salah satu pendekatan terhadap tindakan pelaku usaha yang diduga melanggar UndangUndang Anti Monopoli. Keunggulan rule of reason adalah menggunakan analisis ekonomi untuk mencapai efisiensi guna mengetahui dengan pasti apakah suatu tindakan pelaku usaha memiliki implikasi kepada persaingan.

Manfaat penggunaan metode per se illegal adalah kemudahan dan kejelasannya dalam proses administratif, selain memiliki kekuatan mengikat (self- 
enforcing) daripada larangan-larangan yang masih tergantung pada evaluasi dari pengaruh pasar yang rumit. Sedangkan keuntungan rule of reason adalah dapat mengetahui apakah suatu tindakan pelaku usaha memiliki implikasi terhadap persaingan usaha atau tidak melalui analisis ekonomi.

\section{KESIMPULAN}

Praktik persekongkolan tender diatur dalam Pasal 22 UU No. 5 Tahun 1999 yang dalam pengaturan tersebut mengandung pengertian unsur-unsur persekongkolan antara lain Unsur pelaku usaha; Unsur bersekongkol; Unsur pihak lain; dan Unsur mengatur atau menentukan pemenang tender. Beroperasinya persekongkolan dalam tender antara lain; (1) Tekanan Terhadap Penawaran, (2) Penawaran yang Saling Melengkapi, (3) Perputaran Penawaran atau Arisan Tender, dan (4) Pembagian Pasar. Ruang lingkup persekongkolan dalam Pasal 22 UU No. 5 Tahun 1999 mensyaratkan adanya persekongkolan yang dilakukan oleh para pelaku usaha dengan pihak lain dan adanya kegiatan kolusif yang dilakukan. Dengan sistem elektronik berupa e-procurement dan e-tendering penelusuran terhadap pihak yang diindikasikan bersekongkol dapat dilakukan, hal ini pun yang kemudian dilakukan pada Tender Pekerjaan.

\section{DAFTAR BACAAN}

\section{Buku}

Hansen, Knud dkk., Undang-Undang Larangan Praktek Monopoli dan Persaingan Usaha Tidak Sehat, PT. Tema Baru, Bandung, 2002.

Kagramanto, L. Budi, Larangan Persekongkolan Tender (perspektif hukum persaingan usaha, Srikandi, Surabaya, 2008.

McCoubrey, Hilaire, dan Nigel D. White, Textbook on Jurisprudence, Blackstone Press Ltd., London, 1996.

Munir, Ahmad. "Good Governance on Tax Amnesty" 131, no. Iclgg 2017 (2018): 28-32. https://doi.org/10.2991/iclgg-17.2018.5.

Sudarsono, Kamus Hukum, PT Asdi Mahasatya, Jakarta, 2007.

\section{Penelitian Ilmiah dan Jurnal}

Juwita, Yuliana; 2002, Larangan Persekongkolan Tender Berdasarkan Hukum Persaingan Usaha, Suatu Perbandingan Pengaturan di Indonesia dan Jepang; Universitas Indonesia; Jakarta 
Krisanto, Yakub Adi; 2005; Analisis Pasal 22 UU No. 5 Tahun 1999 dan Karakteristik Putusan KPPU tentang Persekongkolan Tender, Jurnal Hukum Bisnis 24, No. 2 Jakarta

\section{Website}

KPPU, $8,6 \quad$ Trilliun Nilai Persekongkolan Tender, http://www.kppu.go.id/id/blog/2013/01/86-triliun-nilai-persekongkolantender/ diakses pada tangal 21/04/2019, 12:30 WIB

Kamus Besar Bahasa Indonesia, http://kbbi.co.id tanggal 24/05/2019

Matriks Perbedaan Pengaturan Pengadaan Barang dan Jasa - Slide Share https://www.slideshare.net/khalidmustafa1/matriks-perbedaan-perpres-42015dengan-perpres-542010, diakses tanggal 06/05/2019; 10.15 WIB 